\title{
Peningkatan Pengetahuan dan Keahlian Mahasiswa Papua Melalui Pelatihan Interpretasi dan Pengolahan Citra Satelit
}

\author{
Baigo Hamuna ${ }^{1}$, Ervina Indrayani ${ }^{2}$ \\ ${ }^{1}$ Jurusan Ilmu Kelautan dan Perikanan, Fakultas Matematika dan Ilmu Pengetahuan Alam \\ Universitas Cenderawasih, Kota Jayapura, Papua \\ bhamuna@yahoo.com.sg \\ ${ }^{2}$ Jurusan Ilmu Kelautan dan Perikanan, Fakultas Matematika dan Ilmu Pengetahuan Alam \\ Universitas Cenderawasih, Kota Jayapura, Papua \\ ervina_indrayani@yahoo.com
}

\begin{abstract}
Training is very important because the trainees will gain knowledge in theory and practice directly. In addition, training will result in changes the knowledge, skills and attitudes of trainees. The training was carried out to improve the knowledge, skills and expertise of Papuan students in the interpretation and processing of satellite imagery, which would be very useful in the process of managing Papua's natural resources. The method used in this training is the lecture, practice and discussion method. This training was held for two days (August 31, 2018 to September 1, 2018). Training evaluation is conducted using pre-test and post-test. Various motivations of participants to participate in this training include participants wanting to know satellite image processing techniques, knowing map making techniques, and adding skills to be applied in the thesis. The results of the training showed an increase in the knowledge of trainees, where the increase in participants' knowledge was evident from the overall average score at the time of the poet-test was 87.22 compared to the average value at the pre-test only 63.89. Increased skills and expertise of trainees include the ability to interpret and map mangroves with supervised classification methods, determination of mangrove density index and map layout techniques.
\end{abstract}

Keywords: Application of Science and Technology, Community Service, Papuan Students, Training

\begin{abstract}
ABSTRAK
Pelatihan sangat penting karena peserta pelatihan akan memperoleh pengetahuan dalam bentuk teori dan melakukan praktek secara langsung. Selain itu, pelatihan akan menghasilkan perubahan pengetahuan, keterampilan dan sikap peserta pelatihan. Pelatihan ini dilaksanakan untuk meningkatkan pengetahuan, keterampilan dan keahlian mahasiswa Papua dalam interpretasi dan pengolahan citra satelit, yang nantinya sangat bergunan dalam proses pengelolaan sumberdaya alam Papua. Metode yang digunakan pada pelatihan ini adalah metode ceramah, praktek dan diskusi yang dilaksanakan selama dua hari (31 Agustus 2018 sampai 1 September 2018). Evaluasi pelatihan dilakukan menggunakan pre-test dan post-test. Berbagai motivasi peserta untuk mengikuti pelatihan ini antara lain peserta ingin mengetahui teknik pengolahan citra satelit, mengetahui teknik pembuatan peta, dan menambah keterampilan untuk diterapkan dalam skripsi. Hasil pelatihan menunjukkan adanya peningkatan pengetahuan peserta pelatihan, dimana peningkatan pengetahuan peserta terlihat jelas dari nilai rata-rata keseluruhan pada saat post-test adalah 87,22 dibandingkan nilai ratarata pada saat pre-test hanya 63,89. Peningkatan keterampilan dan keahlian peserta pelatihan antara lain keahlian menginterpretasi dan memetakan mangrove dengan metode klasifikasi supervised, penentuan indeks kerapatan mangrove dan teknik layout peta.
\end{abstract}

Kata kunci: Mahasiswa Papua, Pelatihan, Penerapan IPTEKS, Pengabdian Masyarakat

\section{PENDAHULUAN}

Papua memiliki sumberdaya alam pesisir dan laut yang sangat melimpah. Namun, ironisnya sumberdaya alam pesisir dan laut Papua banyak yang telah mengalami degradasi, baik degradasi kondisi, sebaran maupun luasannya. Sebagai contoh, hasil penelitian Hamuna et al. (2018) yang menyatakan bahwa kondisi mangrove di kawasan Taman Wisata Alam Teluk Youtefa telah mengalami degradasi, dimana luas mangrove pada tahun 2017 hanya 233,12 Ha. Degradasi luasan 
mangrove tersebut diperoleh dari hasil pengolahan data citra satelit Landsat multitemporal. Di sisi lain, diperlukan sumberdaya manusia yang handal dan terampil dalam penguasaan ilmu pengetahuan dan teknologi sehingga dapat melakukan pemantauan maupun evaluasi untuk menjawab tantangan dinamika perubahan dan degradasi sumberdaya alam pesisir dan laut Papua. Teknologi informasi memiliki tingkat perkembangan yang sangat pesat dan meliputi berbagai bidang. Salah satunya adalah perkembangan teknologi informasi keruangan, seperti teknologi penginderaan jauh satelit. Penginderaan jauh merupakan ilmu, seni dan teknologi untuk memperoleh informasi tentang suatu objek, daerah atau penomena-penomena melalui analisis data yang diperoleh dari suatu alat tanpa kontak langsung dengan objek, daerah atau fenomenafenomena yang menjadi perhatian (Lillesand and Kiefer, 2000). Dengan menguasai teknologi penginderaan jauh, maka akan mudah dan cepat untuk melakukan pemantauan kondisi suatu sumberdaya alam.

Kualitas pendidikan dan keterampilan sangat menentukan dalam usaha menyiapkan sumberdaya manusia yang handal. Dewasa ini, mahasiswa dituntut untuk menguasai berbagai teknologi dalam melakukan eksplorasi sumberdaya alam pesisir dan laut untuk menunjang pemantauan dan pengelolaan sumberdaya alam melalui proses perkuliahan dan praktikum. Peningkatan penguasaan ilmu dan teknologi tidak hanya dilakukan pada pendidikan formal, namun juga dapat dilakukan melalui pendidikan non-formal dan salah satunya adalah program penerapan IPTEKS. Penerapan IPTEKS pada program pengabdian kepada masyarakat merupakan penerapan hasil-hasil ilmu pengetahuan dan teknologi untuk pemberdayaan serta dapat menghasilkan perubahan pengetahuan, keterampilan dan sikap dari kelompok sasaran (Noor, 2011). Kegiatan penerapan IPTEKS melalui pelatihan dianggap sangat penting karena dalam pelatihan tersebut peserta akan memperoleh materi berupa teori dan melakukan praktek secara langsung.

Pelatihan merupakan sebuah konsep manajemen sumberdaya manusia yang sempit yang melibatkan aktifitas-aktifitas pemberian intruksi khusus yang direncanakan atau pelatihan keahlian (Rowley, 2012). Selanjutnya menurut Dearden (1984) dalam Kamil (2010) yang menyatakan bahwa pelatihan pada dasarnya meliputi proses belajar mengajar dan latihan bertujuan untuk mencapai tingkatan kompetensi tertentu atau efisiensi kerja. Sebagai hasil pelatihan, peserta diharapkan mampu merespon dengan tepat dan sesuai situasi tertentu. Mengingat pentingnya pelaksanaan suatu pelatihan dalam meningkatkan pengetahuan, keterampilan dan kapasitas peserta pelatihan, maka pelatihan yang dilaksanakan diharapkan dapat bermanfaat antara lain (1) peningkatan pemahaman mahasiswa Papua tentang teknologi penginderaan jauh satelit, (2) peningkatan pengetahuan dan keterampilan atau keahlian mahasiswa Papua tentang metode atau teknik interpretasi dan pengolahan citra satelit untuk mendukung pengelolaan sumberdaya alam pesisir Papua, dan (3) peningkatan pengetahuan dan keterampilan atau keahlian mahasiswa Papua tentang metode dan teknik identifikasi degradasi sumberdaya pesisir (mangrove) dengan memanfaatkan sistem informasi geografis.

\section{METODE PELAKSANAAN}

Pelatihan dalam rangka pelaksanaan program penerapan IPTEKS dilaksanakan selama 2 hari yang bertempat di Laboratorium Jurusan Biologi, FMIPA Universitas Cenderawasih. Jumlah peserta pada pelatihan ini sebanyak 20 mahasiswa. Adapun metode pelatihan yang digunakan dalam pelatihan penerapan IPTEKS antara lain:

1. Metode ceramah

Dalam pelatihan ini dibutuhkan dasar pengetahuan tentang teknologi penginderaan jauh dan sistem informasi geografis, sehingga memudahkan peserta untuk memahami proses pembelajaran dalam pelatihan.

2. Metode praktek

Untuk menunjang pelatihan ini maka dibutuhkan sebuah kegiatan pengalaman langsung berupa praktek. Dengan metode praktek maka peserta mampu melakukan simulasi dan menerapkan apa yang telah dipelajari dalam teori. Dalam praktek ini, peserta pelatihan juga diberikan modul atau penuntun pelatihan sebagai panduan untuk melakukan pengolahan data citra satelit. 
3. Metode diskusi

Setiap sesi materi pelatihan baik teori maupun praktek, tim pelaksana juga memberikan kesempatan tanya jawab kepada peserta pelatihan.

Topik pelatihan penerapan IPTEKS dikhususkan pada interpretasi dan pengolahan citra satelit Landsat 8 untuk memetakan sebaran, kerapatan dan degradasi mangrove di Kawasan Teluk Youtefa, Kota Jayapura. Perangkat lunak yang digunakan pada pelatihan ini adalah ErMapper 7.0 dan ArcMap 10.5. Adapun materi pelatihan yang diberikan kepada peserta pelatihan sebagai berikut:

1) Konsep dasar penginderaan jauh satelit dan sistem informasi geografis

2) Citra satelit Landsat

3) Praktek koreksi geometrik dan koreksi radiometrik citra satelit

4) Praktek kombinasi band citra satelit Landsat 8

5) Praktek klasifikasi supervised (klasifikasi terbimbing) untuk mengetahui sebaran mangrove

6) Praktek analisis akurasi klasifikasi citra satelit

7) Praktek analisis tingkat kerapatan mangrove

8) Praktek overlay peta untuk mengetahui tingkat degradasi mangrove

9) Praktek layout peta

Pelatihan ini menerapkan sistem evaluasi yang dilakukan sebanyak dua kali dalam bentuk kuisioner yang bertujuan untuk mengetahui tingkat pemahaman peserta pelatihan sebelum dan setelah pelaksanaan pelatihan. Evaluasi yang dilakukan antara lain:

1) Pre-test yang dilakukan pada awal pelatihan yang bertujuan untuk mengetahui dan mengukur pengetahuan peserta pelatihan tentang sistem penginderaan jauh, citra satelit dan proses pengolahan citra satelit.

2) Post-test yang dilakukan pada akhir pelatihan yang bertujuan untuk mengukur pengetahuan peserta pelatihan tentang sistem penginderaan jauh, citra satelit dan proses pengolahan citra satelit setelah mengikuti pelatihan.

\section{HASIL DAN PEMBAHASAN}

\section{Karakteristik Peserta Pelatihan}

Peserta pelatihan sebanyak 20 mahasiswa yang merupakan mahasiwa Papua, yang terdiri dari 15 mahasiswa Program Studi Ilmu Kelautan dan 5 mahasiswa Program Studi Ilmu Perikanan. Adapun tingkat perolehan informasi dan pemahaman awal peserta pelatihan terhadap topik pelatihan berdasarkan data yang diperoleh melalui kuisioner disajikan pada Tabel 1. Berdasarkan data yang diperoleh, semua peserta pernah mendengar istilah citra satelit, namun sebagian besar belum memahaminya, termasuk pemahaman tentang proses interpretasi dan pengolahan data citra satelit. Selain itu, semua peserta pelatihan belum pernah mengikuti pelatihan pengolahan citra satelit atau pemetaan, sehingga menurut peserta bahwa pelatihan ini akan sangat bermanfaat untuk meningkatkan pengetahuan, keterampilan dan keahlian peserta. Sedangkan motivasi atau tujuan peserta untuk mengikuti pelatihan sebagian besar untuk mengetahui teknik pengolahan citra satelit (Tabel 2).

Tabel 1. Tingkat Pemahaman Awal Peserta Pelatihan

\begin{tabular}{llcc}
\hline No. & Kategori & YA & TIDAK \\
\hline 1 & Pernah mendengar istilah penginderaan jauh dan citra satelit & 20 & 0 \\
2 & Memahami istilah penginderaan jauh dan citra satelit & 8 & 12 \\
3 & Pernah melakukan pengolahan data citra satelit secara mandiri & 6 & 14 \\
4 & Pernah mengikuti pelatihan pengolahan citra satelit atau pemetaan & 0 & 20 \\
\hline
\end{tabular}

Tabel 2. Motivasi Peserta Untuk Mengikuti Pelatihan

\begin{tabular}{llc}
\hline No. & Motivasi & Jumlah \\
\hline 1 & Ingin mengetahui teknik pengolahan citra satelit & 12 \\
2 & Sekedar menambah pengetahuan tentang pengolahan dan pemanfaatan citra & 4 \\
& satelit & \\
\hline
\end{tabular}




\begin{tabular}{lll}
\hline 3 & Ingin mengetahui teknik pembuatan peta & 1 \\
4 & $\begin{array}{l}\text { Menambah keterampilan dan keahlian dalam pengolahan citra satelit untuk } \\
\text { diterapkan dalam Tugas Akhir/Skripsi }\end{array}$ & 3 \\
\hline
\end{tabular}

\section{Pelaksanaan Pelatihan}

Pelatihan dilaksanakan dengan cara tatap muka dan praktek berjalan dengan baik dan lancar. Pertemuan tatap muka dilakukan dengan metode ceramah dan demonstrasi, sedangkan praktek dilaksanakan dengan cara peserta melakukan praktek atau latihan langsung pengolahan citra satelit untuk mendeteksi sebaran, tingkat kerapatan dan degradasi mangrove. Pada pelatihan ini, peserta diberikan langkah-langkah praktif dalam pengolahan citra satelit. Adapun proses pelaksanaan pelatihan sebagai berikut:

a. Pelatihan hari pertama

Pada pelatihan hari pertama, awal kegiatan pelatihan dimulai dengan registrasi peserta pelatihan. Selanjutnya, peserta diberikan pre-test untuk mengetahui pemahaman awal peserta tentang materi pelatihan. Materi pelatihan diberikan melalui ceramah, diskusi dan praktek. Setelah ceramah dan diskusi, peserta akan memulai proses praktek dengan mendapatkan intruksi dan pendampingan dari pelatih. Materi pelatihan pada hari pertama antara lain proses perolehan citra satelit, koreksi data satelit (koreksi radiometrik dan geometrik), kombinasi band citra satelit, klasifikasi supervised citra satelit hingga menghasilkan sebaran mangrove, serta penerapan indeks vegetasi (Normalized Difference Vegetation Index) hingga menghasilkan tingkat kerapatan mangrove. Semua proses praktek pada pelatihan hari pertama dilakukan dengan menggunakan software ErMapper 7.0.

b. Pelatihan hari kedua

Pelatihan hari kedua difokuskan pada praktek mandiri. Peserta pelatihan melakukan praktek interpretasi dan pengolahan citra satelit dengan langkah-langkah pelaksaan seperti pada pelatihan hari pertama atau sesuai modul pelatihan. Citra satelit yang digunakan pada hari kedua adalah citra satelit dengan waktu akuisisi yang berbeda dengan citra satelit pada pelatihan hati pertama. Selain itu, peserta pelatihan juga akan melakukan proses analisis overlay untuk menentukan perubahan luasan mangrove menggunakan software ArcMap 10.5. Sebelum penutupan pelatihan, peserta akan diberikan kembali test teori (post-test) terkait materi pelatihan yang telah diperoleh, dengan tujuan untuk mengetahui tingkat pemahaman peserta setelah mengikuti pelatihan. Selain itu, peserta akan diberikan kuisioner sebagai bahan evaluasi pelaksanaan pelatihan.

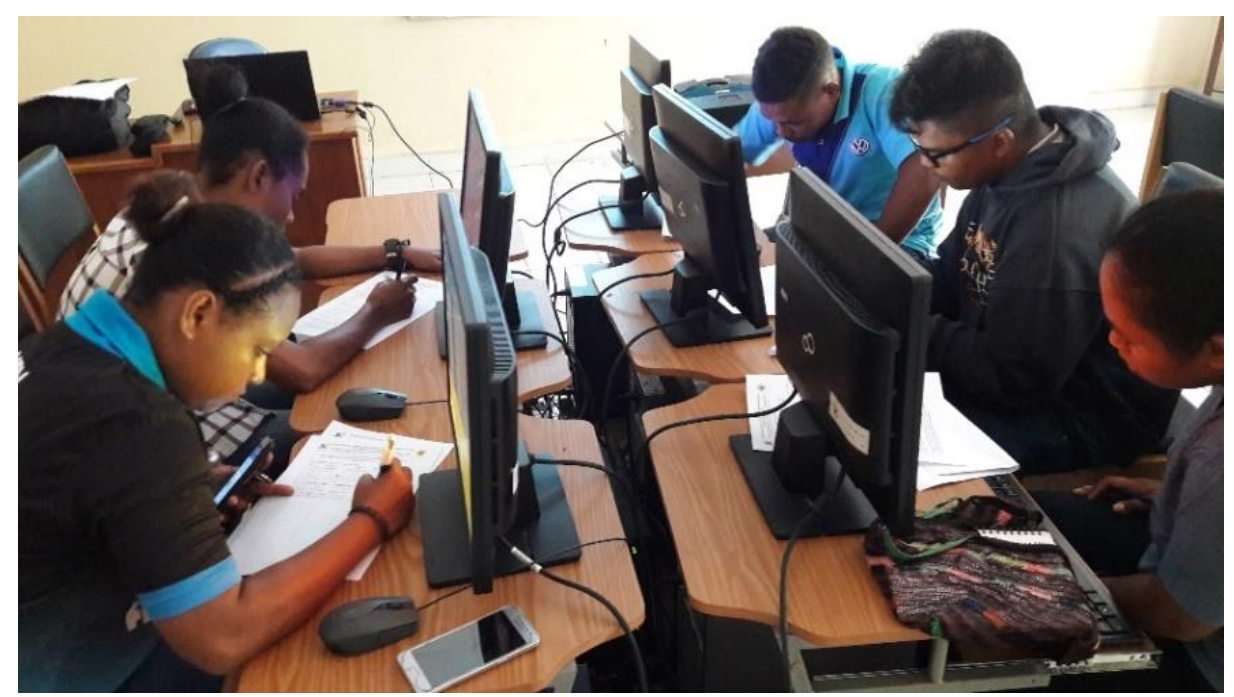

Gambar 1. Peserta Pelatihan Sedang Mengisi Kuisioner Pada Saat Pre-Test 


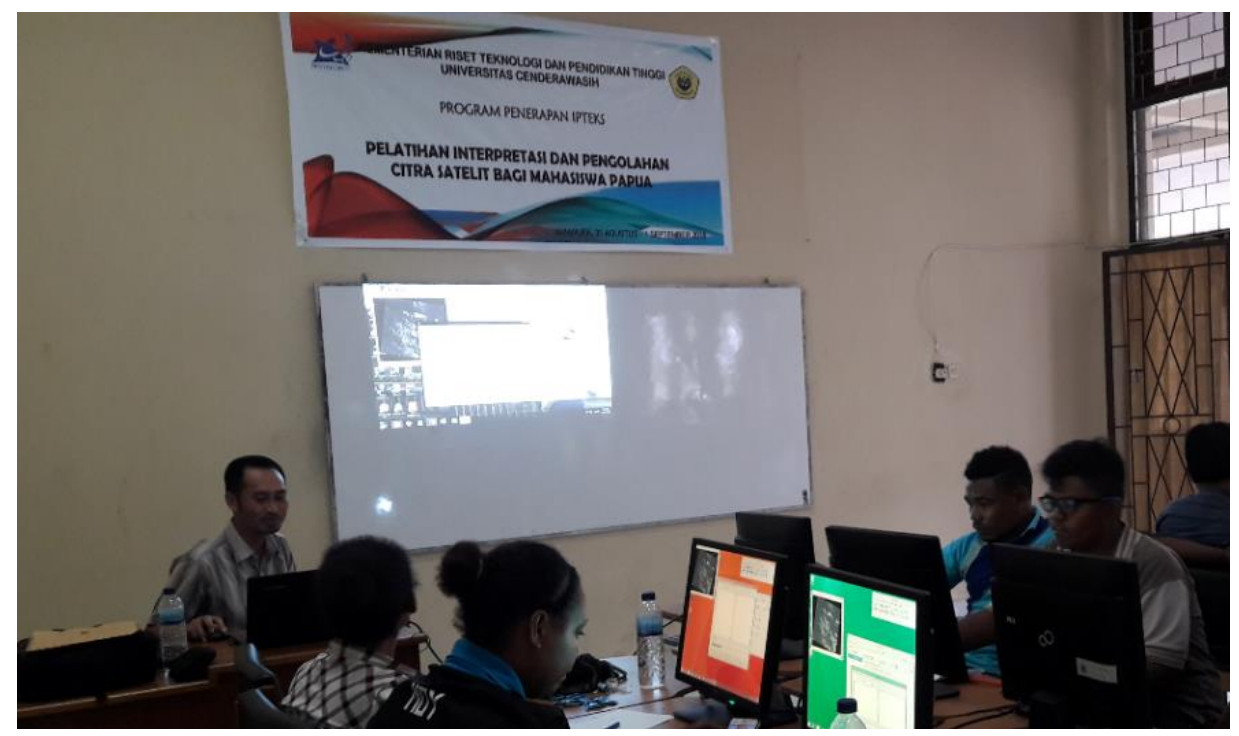

Gambar 2. Pelatih Membimbing Peserta Pelatihan Menggunakan Media Infokus

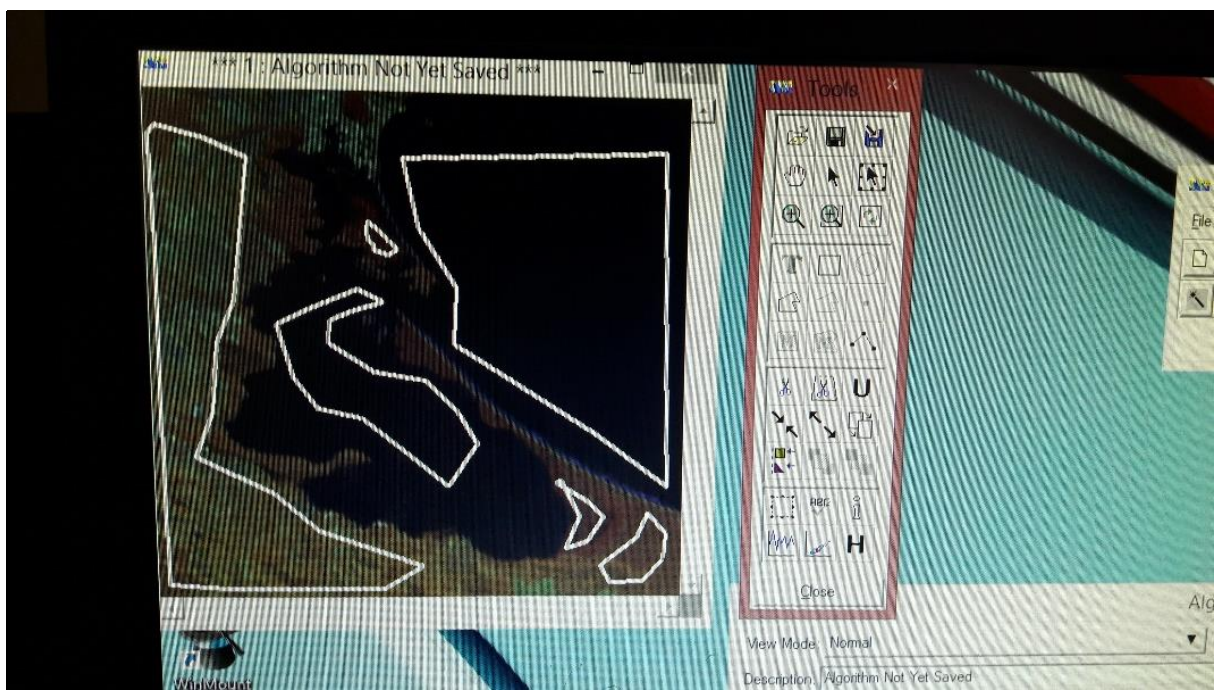

Gambar 3. Contoh Hasil Pembuatan Region Untuk Proses Klasifikasi Supervised

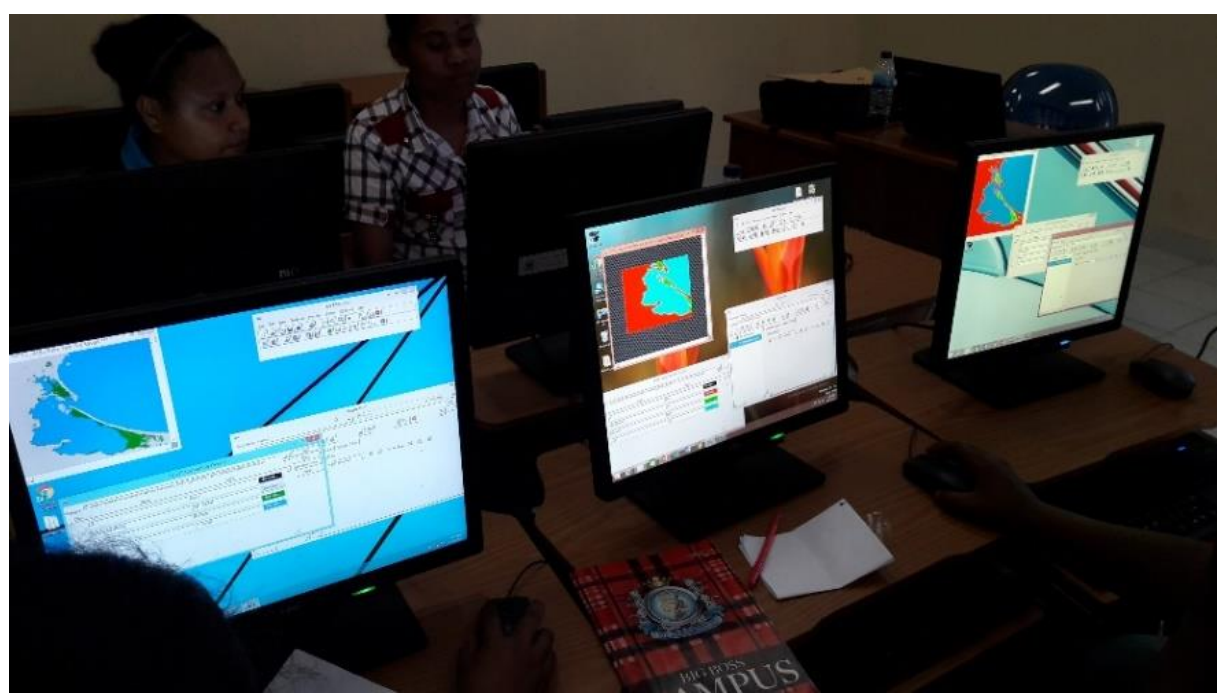

Gambar 4. Peserta Melakukan Pengolahan Citra Satelit dengan Klasifikasi Supervised 


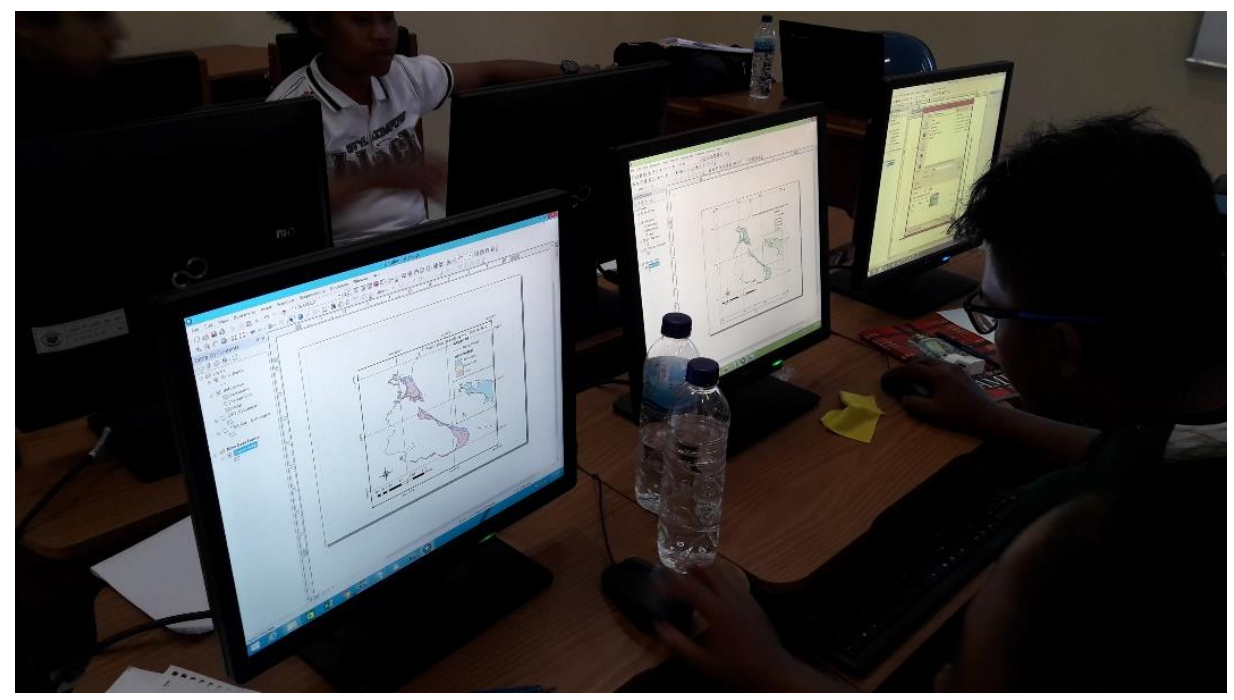

Gambar 5. Peserta Melakukan Proses Layout Peta

\section{Evaluasi Pelatihan}

Evaluasi pelatihan merupakan suatu metode untuk menentukan efektifitas dari suatu program pelatihan (Kirkpatrick, 1994). Efektifitas pelatihan berkaitan dengan sejauh mana program pelatihan yang diselenggarakan mampu mencapai apa yang telah diputuskan sebagai tujuan yang harus dicapai (Irianto, 2001). Untuk menilai tingkat keberhasilan pelatihan yang dilaksanakan, maka peserta pelatihan diberikan angket pertanyaan yang dijawab secara bebas tentang peningkatan pemahaman peserta selama mengikuti pelatihan. Semua peserta pelatihan menyatakan bahwa ada peningkatan pemahaman dalam pengolahan citra satelit, yang diantaranya tentang (1) interpretasi dan memetakan mangrove dengan metode klasifikasi supervised, (2) penentuan indeks kerapatan mangrove, dan (3) teknik layout hasil dalam bentuk peta. Untuk tingkat kepuasan peserta pelatihan antara lain 30\% menyatakan cukup puas dan 70\% menyatakan sangat puas terhadap pelaksanaan pelatihan.

Pelatihan ini juga menerapkan evaluasi dalam bentuk pre-test dan post-test, dimana peserta pelatihan menjawab pertayaan yang disediakan dalam bentuk pertanyaan pilihan ganda. Penilaian pre-test dan post-test dilakukan dengan memberi skor 100 untuk setiap jawaban yang benar dan kemudian dijumlahkan lalu dibagi dengan jumlah soal. Topik soal anata lain konsep dasar penginderaan jauh, teknik pengolahan citra satelit, dan manfaat citra satelit, dimana setiap topik yang masing-masing terdiri dari 3 soal. Gambar 4 menyajikan grafik perbandingan hasil pre-test dan post-test peserta pelatihan berdasarkan topik soal. Dari perbandingan hasil pre-test dan posttest tersebut dapat dilihat bahwa seluruh peserta pelatihan mengalami peningkatan pengetahuan pada 3 topik pelatihan yang dilakukan, dimana peningkatan tertinggi terjadi pada pengetahuan peserta tentang konsep dasar penginderaan jauh sebesar $41,67 \%$, teknik pengolahan citra satelit sebesar $13,33 \%$ dan manfaat citra satelit sebesar $10 \%$. Peningkatan pengetahuan peserta juga terlihat jelas dari adanya peningkatan nilai rata-rata hasil test peserta pelatihan, dimana nilai ratarata keseluruhan pada saat pre-test hanya sebesar 63,89 dan meningkat menjadi 87,22 pada saat post-test (Gambar 5). 


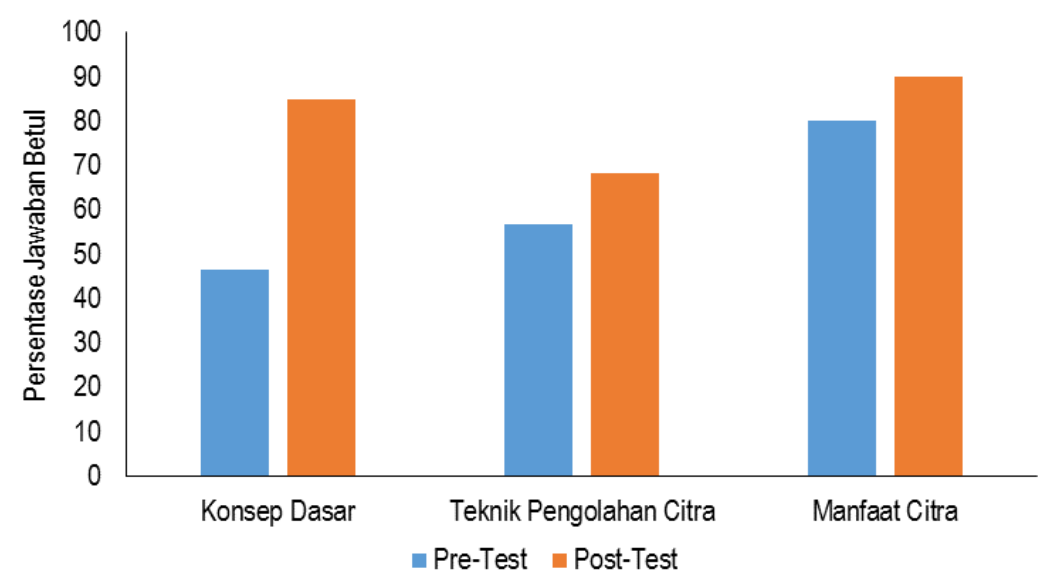

Gambar 4. Perbandingan Pengetahuan Peserta Pelatihan Berdasarkan Kelompok Soal

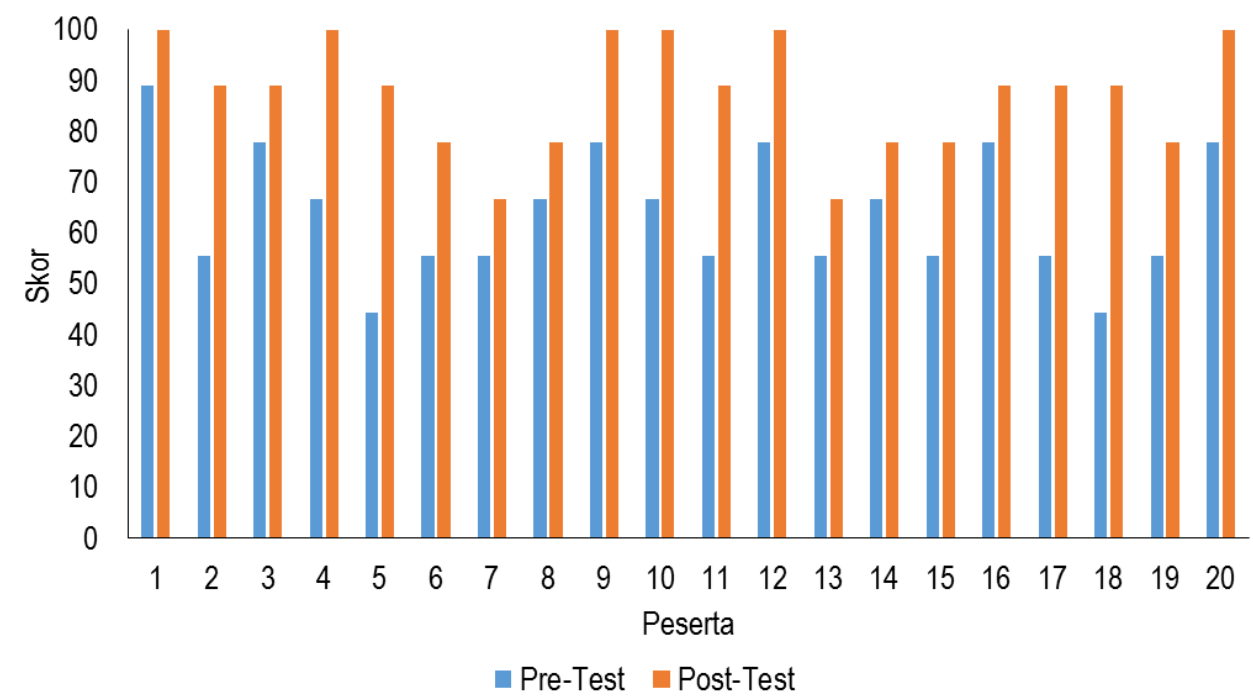

Gambar 5. Peningkatan Pengetahuan Peserta Berdasarkan Hasil Pre-Test dan Post-Test

\section{KESIMPULAN}

Secara keseluruhan, kegiatan pelatihan yang dilakukan dalam rangka penerapan IPTEKS berjalan dengan baik. Berbagai motivasi peserta untuk mengikuti pelatihan ini, antara lain peserta ingin mengetahui teknik pengolahan citra satelit, mengetahui teknik pembuatan peta, dan menambah keterampilan untuk diterapkan dalam skripsi. Berdasarkan perbandingan hasil pre-test dan posttest, terdapat peningkatan pengetahuan peserta pelatihan, dimana seluruh peserta pelatihan mengalami peningkatan pengetahuan pada 3 topik pelatihan yang dilakukan. Peningkatan pengetahun peserta juga terlihat jelas dari adanya peningkatan nilai rata-rata hasil test peserta pelatihan, dimana nilai rata-rata keseluruhan pada saat pre-test hanya sebesar 63,89 dan meningkat menjadi 87,22 pada saat post-test. Peningkatan keterampilan dan keahlian peserta pelatihan antara lain keahlian menginterpretasi dan memetakan mangrove dengan metode klasifikasi supervised, penentuan indeks kerapatan mangrove dan teknik layout hasil dalam bentuk peta.

\section{UCAPAN TERIMA KASIH}

Penulis menyampaikan terima kasih kepada Lembaga Penelitian dan Pengabdian Kepada Masyarakat (LPPM) Universitas Cenderawasih atas bantuan pendanaan melalui hibah Program Penerapan IPTEKS tahun 2018. Penulis juga menyampaikan terima kasih kepada pengelola Laboratorium Komputer Jurusan Biologi yang telah menyediakan fasilitas penunjang pelaksanaan pelatihan. 


\section{DAFTAR PUSTAKA}

Hamuna, B., Sari, A. N., dan Megawati, R., (2018). Kondisi Hutan Mangrove di Kawasan Taman Wisata Alam Teluk Youtefa, Kota Jayapura. Majalah Ilmiah Biologi Biosfera: A Scientific Journal, 35(2), pp. 75-83.

Irianto, Y., (2001). Prinsip-Prinsi Dasar Manajemen Pelatihan. Surabaya: Insan Cendekia.

Kamil, M., (2010). Model Pendidikan dan Pelatihan. Bandung: Alfabeta.

Kirkpatrick, D., (1994). Evaluating Training Programs. The Four Level. Berrett Koehler Publisher Inc.

Lillesand, T. M. and Kiefer, R. W., (2000). Remote Sensing and Image Interpretation. Four Edition. New York: John Wiley \& Sons Inc.

Noor, I. H. M., (2011). Pemanfaatan Ilmu Pengetahuan dan Teknologi Dalam Kegiatan Pengabdian Masyarakat di Perguruan Tinggi. Jurnal Pendidikan dan Kebudayaan, 17(3), pp. 306-315.

Rowley, C., (2012). Manajemen Sumber Daya Manusia. Jakarta: Rajawali Pers. 